\title{
Relationship of COVID-19 Pandemic with Anxiety, Anger, Sleep and Emotion Regulation in Healthcare Professionals
}

\section{COVID-19 Pandemisinin Sağlık Çalışanlarında Kaygı, Öfke, Uyku ve Duygu Düzenleme ile İlişkisi}

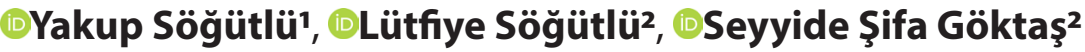 \\ University of Health Sciences Istanbul Ümraniye Training and Research Hospital, Pediatric Emergency Clinic, Istanbul, Turkey \\ 2University of Health Science, Faculty of Life Science, Department of Psychology, Istanbul, Turkey
}

\begin{abstract}
Objective: Epidemic diseases have caused significant mental responses throughout the society and especially healthcare professionals, as well as those who have been infected. Healthcare professionals have a big role in the fight against the new coronavirus infection (COVID-19). When the literature is reviewed in terms of risky professions, as the cases increase, the psychological influence has increased significantly among the healthcare professionals dealing with the care of patients as an occupational group. The aim of this study is to research the effect of pandemic on anxiety, anger, sleep and emotion regulation in healthcare professionals.
\end{abstract}

Material and Method: The study included 261 doctors and 145 nurses. Data were collected by the Sociodemographic Data Form, State-Trait Anxiety Inventory (STAI), State-Trait Anger Expression Inventory (STAEI), Insomnia Severity Index (ISI) and Difficulties in Emotion Regulation Scale (DERS).

Results: State anxiety levels $50.5 \%$, anger levels $34.8 \%$, insomnia severity levels $35.4 \%$ and $36.1 \%$ of emotion regulation difficulty levels were detected of healthcare professions. It was determined that the state anxiety level increases the levels of trait anger and insomnia severity, the level of emotion regulation difficulty increases the levels of trait anger and the level of insomnia severity increases the level of trait anger of healthcare professions significantly.

Conclusion: We consider that the study will be guiding in terms of the degree of mental response of the healthcare professionals and the psychological and social support to be given to this group after the pandemic.

Keywords: COVID-19, anxiety, anger, insomnia, emotion regulation, frontline healthcare workers
Öz

Amaç: Salgın hastalıklar tarih boyunca hastalığa yakalananlar kadar tüm toplumda ve özellikle de sağlık çalışanlarında önemli ruhsal etkilenmelere yol açmıştır. Yeni coronavirus enfeksiyonu (COVID-19) ile mücadelede sağlık çalışanlarının rolü büyüktür. Riskli meslekler açısından literatür incelendiğinde; vakalar arttıkça meslek grubu olarak hastaların bakımı ile ilgilenen sağlık personellerinde hastalık ciddi artış göstermiştir. Bu çalışmada amacımız; COVID-19 pandemisinden fiziksel ve ruhsal olarak ciddi biçimde etkilenen sağlık çalışanlarında pandeminin kaygı, öfke, uyku ve duygu düzenleme üzerine etkisini araştırmaktır.

Gereç ve Yöntem: Araştırmaya 406 sağlık çalışanı (261 hekim, 145 hemşire) dahil edilmiştir. Araştırmada Sosyodemografik Veri Formu, Durumluk Kaygı Ölçeği (DKÖ), Sürekli Öfke Ölçeği (SÖÖ), Uykusuzluk Şiddeti Ölçeği (Uşi) ve Duygu Düzenleme Güçlüğü Ölçeği (DDGÖ) ile veriler toplanmıştır.

Bulgular: Sağlık çalışanlarının durumluk kaygı düzeylerinin $\% 50,5$, sürekli öfke düzeylerinin \%34,8, uykusuzluk şiddeti düzeylerinin $\% 35,4$ ve duygu düzenleme güçlüğü düzeylerinin \%36,1 olarak tespit edildi. Sağıık çalışanlarının durumluk kaygı düzeyinin sürekli öfke ve uykusuzluk şiddeti düzeylerini, duygu düzenleme güçlüğü düzeyinin sürekli öfke düzeylerini ve uykusuzluk şiddeti düzeyinin sürekli öfke düzeylerini anlamlı olarak arttırdığı tespit edilmiştir.

Sonuç: Çalışmamızın sağlık çalışanlarının ruhsal açıdan hem pandemiden etkilenme dereceleri açısından hem de pandemi sonrası bu gruba verilecek ruhsal ve sosyal destek açısından yol gösterici olacağı kanaatindeyiz.

Anahtar Kelimeler: COVID-19, kaygı, öfke, uykusuzluk, duygu düzenleme, sağlık çalışanı 


\section{INTRODUCTION}

Coronavirus disease 2019 (COVID-19) was declared as an international public health state of emergency and pandemia by the World Health Organization (WHO) with the detection of infection in 34 regions of China on 30 January 2020. The agent that is the cause of pneumonia has been identified as a new coronavirus and is defined as severe acute respiratory syndrome coronavirus 2 (SARS-CoV-2). The source of infection was identified as a bat and with the formation of 15 sets of healthcare professionals all of which were infected by an infected patient, the pathogen showed a rapid pattern of transmission from person to person. In Wuhan, China's Hubei province, where the infection was first identified, the infection grew exponentially and spread rapidly across the World..$^{1-5}$

One of the groups that are seriously affected physically and psychologically by this negative situation is healthcare professionals. Continuously increasing number of cases, increasing workload, constantly updating information about the disease, depletion of personal protection equipment, widespread media exposure, lack of specific medicines, inadequate support, the risk of transmission of the infection and the risk of carrying the disease home increased the mental burden of healthcare professionals. ${ }^{6-8}$ According to July 2020 data Ministry of Health of Turkey, a total of 8 thousand 227 healthcare professionals (the ratio of the average number of cases, 7.2\%) have been infected. ${ }^{9}$

Healthcare professionals, especially those who care for COVID-19 patients have become more touchy to both high risk of infection and mental influence. A study in China has shown that those who are at the highest risk for mental illness; young people, healthcare professionals and people who spend a lot of time thinking about pandemia. ${ }^{10}$

Disease-induced stigma and feeling of loneliness that is brought by stigmatize can be added to the stress of those struggling with the disease and their relatives. Depression, feeling of loneliness, helplessness, hopelessness, anxiety and panic feeling, intense fears, irritability, intolerance, bursts of anger, unwillingness, difficulty in concentration, excessive mental struggles and thoughts, sleep and appetite problems, physical problems can take part in human lives as mental problems that everyone can experience. ${ }^{11}$

Anxiety can be expressed as a state of fear and tension felt under a threat. State anxiety is the fear that the individual feels due to the stressful situations person in and is an indication of the individual's emotions of tension and uneasiness. Moreover, individuals who experience state anxiety frequently are also at risk of becoming trait anxiety and many other anxiety situations may follow (social, somatic, etc.). ${ }^{12}$ The emergence and consequences of COVID-19 caused worldwide fear, concern and anxiety among people. With the determination of high risk of transmission and mortality rates of the infection, people as a matter of course have begun to worry and concern about COVID-19. Anxiety and fear can increase the damage caused by the disease. Individuals may not think clearly and straight when reacting to COVID-19 with high levels of fear and anxiety. ${ }^{13,14}$ Differences were determined between medical and non-medical healthcare professionals in terms of symptoms of depression, anxiety, stress and post-traumatic stress disorder. These differences can also be a guide for post-pandemic rehabilitation studies. ${ }^{15}$

Anger is an emotion, thinking that deliberately misdone to one's self, characterized by feeling hostility towards someone or something. The feeling of anger, which plays a very important role in daily life, occurs when the person is faced with obstructiveness. Conditions that cause anger which is one of the universal emotions and the way anger is expressed varies according to several factors such as age, gender, education level, work environment and culture. ${ }^{16}$ In infectious disease pandemias, the risk of infection in healthcare professionals, changing working conditions, although protective equipment is sufficient uncertainty how long the situation will last, fear of carrying the disease, disease-induced stigma may cause an increase in anger. ${ }^{17}$ Furthermore, increased anxiety, severity of insomnia and emotion regulation difficulties can increase anger.

Light, lifestyle, meal times, physical activity and stress level are important in the sleep wake cycle. In the pandemia situation, the change of overtime period and working order, increased anxiety and depression levels of healthcare professionals not only affect daily life but also sleep. ${ }^{18}$ In addition, a study showed that; anxiety, depression and stress levels and physical symptoms increased in healthcare professionals during pandemia. $^{19}$

Emotion regulation often involves changes in emotional response. During emotion regulation, the person can increase, sustain or decrease the intensity of their positive or negative emotions. ${ }^{20}$ Emotional regulation and management play a determining role in health protection and mental disorders. ${ }^{21}$ Increasing anxiety level in pandemia situation is likely to accompany emotional regulation difficulty, anger and insomnia.

The purpose of this study is to research the effect of pandemia on anxiety, anger, sleep and emotion regulation in healthcare professionals who are severely affected physically and mentally by the COVID-19 pandemia. It is also aimed to examine the effect of these variables on each other. Especially when reviewing the literature on COVID-19, the effects of pandemia on depression, anxiety, post-traumatic stress disorder and sleep in healthcare professionals were searched, and there was no research article on the effect of anger and emotion regulation difficulty.

\section{MATERIAL AND METHOD}

\section{Sample}

The universe of the research consists of doctors and midwives/ nurses in Turkey. According to the data of the Ministry of Health in 2020, the number of doctors and midwives/nurses working in Turkey is approximately 370,332 . With the sampling error of 0.05 from the universe, considering the reliability ${ }^{22}$ the number 
of sub-participation was determined as 384 and 406 doctors and midwives/nurses who work actively were included in the study. Socio-demographic data form and scales containing questionnaire form were prepared by Google Drive program and applied to participants by sharing it via social media groups and e-mail. Repeating access was blocked by the programme for participants to do the tests one more time.

\section{Data Collection Tool}

Online survey method was used by using Google Drive program to collect the research data. In the survey; totally 5 sections ranked as sociodemographic data form, State-Trait Anxiety Inventory (STAI), State-Trait Anger Expression Inventory (STAEI), Insomnia Severity Index (ISI) and Difficulties in Emotion Regulation Scale (DERS).

Sociodemographic Data Form: Questions about sociodemographic characteristics such as age and gender etc. of the participants and Covid-19 were prepared and posed by the researcher.

State-Trait Anxiety Inventory (STAI): It is a 40-item self-report scale developed by Spielberger to measure the state and trait anxiety level of the individual. ${ }^{23}$ The inventory consists of two different sub-scales: state anxiety and trait anxiety. In this study, state anxiety sub-scale was used. The Turkish validity and reliability study were conducted by Öner et al. ${ }^{24}$ provides fourpoint likert-type measurement.

State-Trait Anger Expression Inventory (STAEI): It was developed by Spielberger et al. ${ }^{25}$ and the trait anger subscale of the scale was used in our study. It was adapted to Turkish by $\mathrm{Ozer}^{26}$ and is a 4-point likert-type scale with 10 items.

Insomnia Severity Index (ISI): It is a measurement tool developed to evaluate the severity of insomnia and has high validity and reliability. ${ }^{27}$ Scale items consisting of seven questions are scored between 0-4. The scores that can be obtained from the scale vary between $0-28$. Turkish validity and reliability study were made by Boysan et al. ${ }^{28}$

Difficulties in Emotion Regulation Scale (DERS): It is a 5-point likert-type scale consisting of 36 items developed by Gratz and Roemer. ${ }^{29}$ High scores from the scale indicate high level of emotion regulation difficulties. Adaptation of the scale to Turkish, validity and reliability studies were conducted by Ruganc and it was reported to be a valid and reliable measurement tool. ${ }^{30}$

\section{Process}

Ethics committee approval for the study, numbered 46418926-050.03.04, dated 24.04.2020, was received from Hamidiye Scientific Research Ethics Committee of Health Sciences University. A questionnaire application including sociodemographic data form and scales was applied to 406 doctors and midwives/nurses who work actively in Turkey between the dates of 25-29 April 2020. Those with a history of psychiatric illness and using psychiatric medication were not included in the study.

\section{Data Analysis}

In the analysis of the data collected within the scope of the research, quantitative analysis method was employed by using SPSS 24.0 program. Within the scope of quantitative analysis; descriptive statistical methods such as mean, standard deviation, percentage, skewness and kurtosis and simple linear (regression) analysis, with $p<0.05$ significance level and $95 \%$ confidence interval were used.

In addition, it was decided whether the data shows normal distribution or not by examining the skewness and kurtosis coefficients. The skewness and kurtosis values in the range of \pm 1.50 are interpreted as normal distribution. ${ }^{31}$ In the study, the skewness and kurtosis coefficients of the state anxiety total score were -0.206 and -0.433 , of the trait anger total score 0.675 and 0.425 , of the total score of insomnia severity are 0.655 and 0.155 ,of the emotion regulation difficulty total score included in the regression were found to be 0.376 and -0.112 .

\section{RESULTS}

A total of 406 doctors and midwives/nurses working in Turkey in April 2020 were included in this study which was conducted to examine the correlation of Covid-19 pandemic with anger, anxiety, sleepand emotion regulation in healthcare professionals. In the study, 236 (58.1\%) women and 170 (41.9\%) men, 261 (64.3\%) doctors, 145 (35.7\%) midwives/nurses participated. The average age of healthcare professionals, ranging in age from 21 to 62 , is $35.57 \pm 8.66$. As a marital status, $262(64.5 \%)$ of the participants are married, $126(31.1 \%)$ are single, $16(3.9 \%)$ are divorced and $2(0.5 \%)$ are widows (spouse passed away). Also, 171 (42.1\%) of the participants did not have children, $72(17.7 \%)$ had 1 child, 112 (27.6\%) had 2 children, 40 (9.8\%) had 3 children, $11(2.7 \%)$ have 4 or more children. The average daily working hours of the participants are $11.94 \pm 6.76$ and the average number of hospital watches per week is $1.73 \pm 1.77$.

Participants, 262 people (65.4\%), work with patients treated for COVID-19 and 141 (34.7\%) have a history of contact with COVID-19. The number of participants who received the COVID-19 test was $156(38.4 \%)$ and of those 21 (13.5\%) were positive, $135(86.5 \%)$ were negative and $3(1.9 \%)$ participants were hospitalized. Near of kin of $16(3.9 \%)$ participants were diagnosed with COVID-19. On the other hand, the number of those who think that they have sufficient protective equipment while working is 260 (64.0\%). Moreover, 363 (89.4\%) of the participants are concerned about transmitting COVID-19 to people in their homes and $342(84.2 \%)$ to people outside of hospitals or other health institutions.

Healthcare professionals' included the study the average of state anxiety was $50.30 \pm 10.56$, the average of trait anger was $20.45 \pm 5.52$, the average of insomnia was $9.92 \pm 5.75$ and the emotion regulation difficulties were $87.96 \pm 18.01$ found to be. Descriptive statistics on the state anxiety, trait anger, insomnia severity and emotion regulation difficulty levels of the healthcare professionals included in the study are given in Table $\mathbf{1}$. 


\begin{tabular}{|c|c|c|c|c|c|}
\hline & Min. & Max. & Mean & Sd. & $\% *$ \\
\hline State Anxiety & 20.00 & 75.00 & 50.30 & 10.56 & 50.5 \\
\hline Trait Anger & 10.00 & 40.00 & 20.45 & 5.52 & 34.8 \\
\hline Insomnia Severity & 0.00 & 28.00 & 9.92 & 5.75 & 35.4 \\
\hline Emotion Regulation Difficulty & 52.00 & 143.00 & 87.96 & 18.01 & 36.1 \\
\hline
\end{tabular}

It was found that the state anxiety level of women and midwives/nurses was significantly higher than that of men and doctors; trait anger levels of healthcare professionals under the age of 35 are significantly higher than those aged 35 and over; insomnia severity levels of women, midwives/nurses, healthcare professionals under the age of 35 , single/widowed/ divorced, working 9 hours or more per day and those who have 2 or more hospital watches per week are significantly higher; women's emotion regulation difficulty levels were significantly higher than men $(p<0.05)$. Apart from these, no significant difference was found ( $p>0.05$ ).

The findings obtained as a result of comparing the state anxiety, trait anger, insomnia severity, and emotion regulation difficulty according to demographic characteristics are given in Table 2.

When the general situation was reviwed, it was found that the state anxiety level of the healthcare professionals showed a positive correlation with the trait anger levels $(B=0.213 ; p<0.01$ ). Accordingly, as the level of anxiety measured in healthcare professionals increases, anger levels may also increase.
The findings obtained as a result of simple linear regression analysis to determine the effect of state anxiety on trait anger are given in Table 3.

When the general situation was reviwed, it was found that the state anxiety level of the healthcare professionals showed a positive correlation with the insomnia severity levels $(B=0.392$; $p<0.01$ ). Accordingly, as the level of anxiety measured in healthcare professionals increases, there can be an increase in the level of insomnia severity.

Simple linear regression analysis findings to determine the effect of state anxiety on insomnia severity are given in Table 4.

When the general situation was reviwed, it was found that the level of insomnia severity of healthcare professionals was positively correlated with trait anger levels $(B=0.304$; $p<0.01$ ). Accordingly, as the severity of insomnia in healthcare professionals decreases, there can be a significant decrease in anger level.

Simple linear regression analysis findings to determine the effect of insomnia severity on trait anger are given in Table $\mathbf{5}$.

\begin{tabular}{|c|c|c|c|c|c|c|c|}
\hline \multirow{2}{*}{ Variable } & \multirow{2}{*}{ Group } & \multirow{2}{*}{ Model } & \multicolumn{2}{|c|}{ Unstandardized Coefficients } & \multirow{2}{*}{$\begin{array}{c}\text { Standardized Coefficients } \\
\text { B }\end{array}$} & \multirow{2}{*}{$\mathbf{t}$} & \multirow{2}{*}{$\mathbf{p}$} \\
\hline & & & B & S. Error & & & \\
\hline General Situation & & Constant & 14.861 & 1.306 & 0.213 & 4.375 & $0.000^{*}$ \\
\hline \multirow{2}{*}{ Profession } & \multirow{2}{*}{ Doctor } & Constant & 15.182 & 1.608 & \multirow{2}{*}{0.194} & \multirow{2}{*}{3.184} & \multirow{2}{*}{$0.002^{*}$} \\
\hline & & State Anxiety & 0.103 & 0.032 & & & \\
\hline \multirow{4}{*}{ Gender } & \multirow{2}{*}{ Female } & Constant & 15.776 & 1.704 & \multirow{2}{*}{0.180} & \multirow{2}{*}{2.800} & \multirow{2}{*}{$0.006^{*}$} \\
\hline & & State Anxiety & 0.089 & 0.032 & & & \\
\hline & \multirow{2}{*}{ Male } & Constant & 12.627 & 2.160 & \multirow{2}{*}{0.274} & \multirow{2}{*}{3.698} & \multirow{2}{*}{$0.000^{*}$} \\
\hline & & State Anxiety & 0.165 & 0.045 & & & \\
\hline $\begin{array}{l}\text { Result of Covid-19 } \\
\text { Test }\end{array}$ & Pozitive & Constant & 10.727 & 6.518 & 0.354 & 1.651 & 0115 \\
\hline History of Covid-19 & Yes & State Anxiety & 0.120 & 0.045 & 0.221 & 2.668 & $0.009^{\circ}$ \\
\hline Contact & $\mathrm{Ne}$ & Constant & 14.868 & 1.578 & 0206 & 3420 & $0001 *$ \\
\hline & NO & State Anxiety & 0.105 & 0.031 & 0.200 & $3.4 \angle 0$ & 0.001 \\
\hline & Yes & Constant & 9.134 & 18.852 & 0.373 & 0.402 & 0.757 \\
\hline Hospitalization & Yes & State Anxiety & 0.165 & 0.411 & $0.3 / 3$ & & \\
\hline Tuspranizationti & $\mathrm{No}$ & Constant & 16.481 & 2.312 & 0166 & 2069 & $0.040^{*}$ \\
\hline & NO & State Anxiety & 0.091 & 0.044 & 0.166 & 2.003 & $0.0+0$ \\
\hline
\end{tabular}




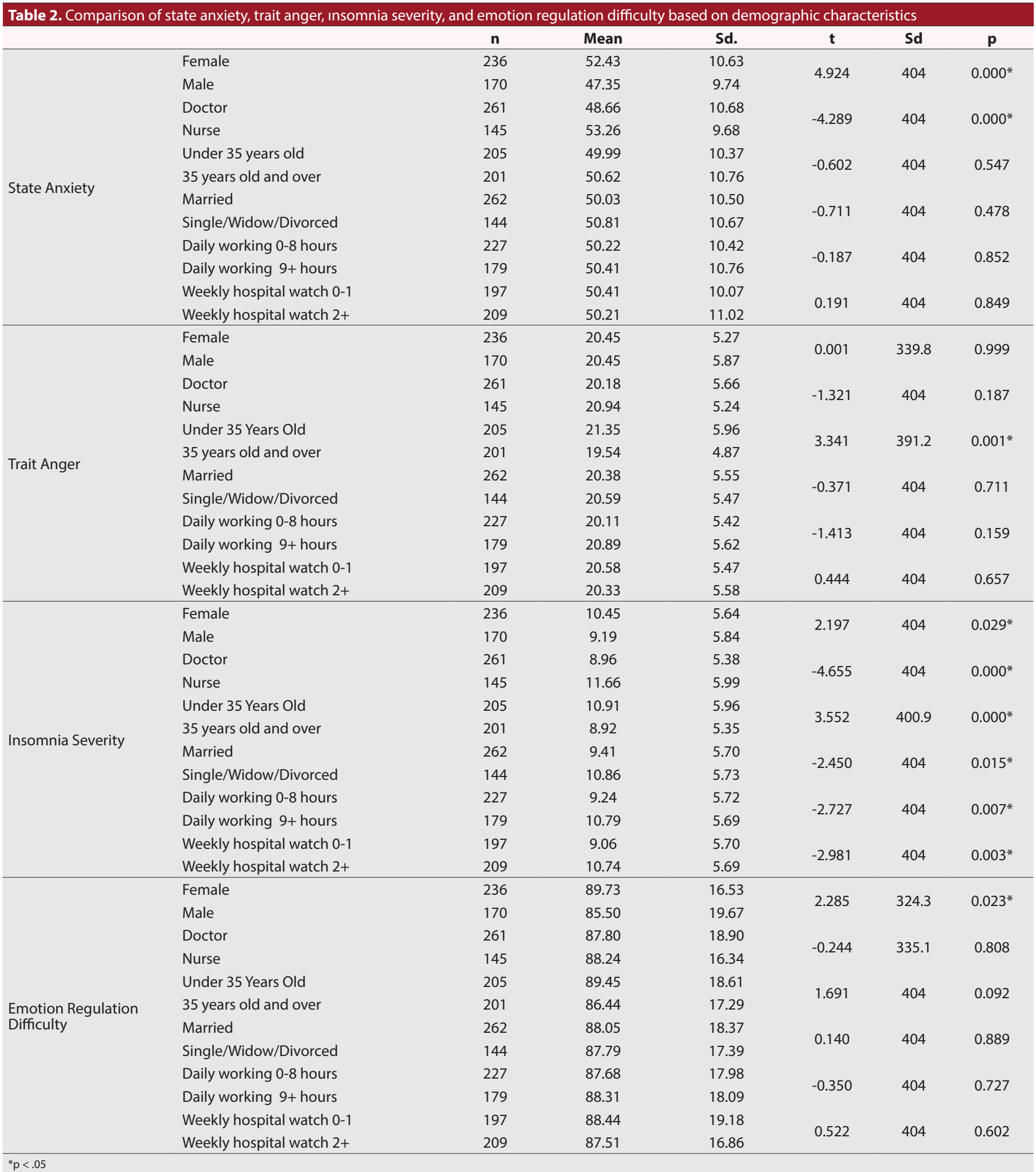

When the general situation was reviwed, it was found that the level of emotional regulation difficulties of healthcare professionals was positively correlated with trait anger levels $(ß=0.492 ; p<0.01)$. Accordingly, emotion regulation difficulty in healthcare professionals predicts trait anger significantly.

Simple linear regression analysis findings to determine the effect of emotion regulation difficulty on trait anger are given in Table 6. 


\begin{tabular}{|c|c|c|c|c|c|c|c|}
\hline \multirow{2}{*}{ Variable } & \multirow{2}{*}{ Group } & \multirow{2}{*}{ Model } & \multicolumn{2}{|c|}{ Unstandardized Coefficients } & \multirow{2}{*}{$\begin{array}{c}\text { Standardized Coefficients } \\
\text { B }\end{array}$} & \multirow{2}{*}{$\mathbf{t}$} & \multirow{2}{*}{$\mathbf{p}$} \\
\hline & & & В & S. Error & & & \\
\hline \multirow{2}{*}{ General Situation } & & Constant & -0.821 & 1.281 & \multirow{2}{*}{0.392} & \multirow{2}{*}{8.568} & \multirow{2}{*}{$0.000^{*}$} \\
\hline & & State Anxiety & 0.214 & 0.025 & & & \\
\hline \multirow{2}{*}{ Profession } & \multirow{2}{*}{ Doctor } & Constant & 0.471 & 1.464 & \multirow{2}{*}{0.346} & \multirow{2}{*}{5.936} & \multirow{2}{*}{$0.000^{*}$} \\
\hline & & State Anxiety & 0.174 & 0.029 & & & \\
\hline \multirow{4}{*}{ Gender } & \multirow{2}{*}{ Female } & Constant & -0.100 & 1.716 & \multirow{2}{*}{0.379} & \multirow{2}{*}{6.274} & \multirow{2}{*}{$0.000^{*}$} \\
\hline & & State Anxiety & 0.201 & 0.032 & & & \\
\hline & \multirow{2}{*}{ Male } & Constant & -1.627 & 2.068 & \multirow{2}{*}{0.381} & \multirow{2}{*}{5.339} & \multirow{2}{*}{$0.000^{*}$} \\
\hline & & State Anxiety & 0.228 & 0.043 & & & \\
\hline & Yes & Constant & -0.391 & 2.071 & 0.399 & 5.132 & $0.000 *$ \\
\hline History of Covid-19 & res & State Anxiety & 0.205 & 0.040 & & & \\
\hline Contact & $\mathrm{No}$ & Constant & -1.035 & 1.628 & 0380 & 6850 & $0 \cap 000$ * \\
\hline & INO & State Anxiety & 0.218 & 0.032 & 0.309 & 0.050 & 0.000 \\
\hline & Yes & Constant & -35.273 & 20.081 & 0.905 & 2133 & 0.279 \\
\hline Hosnitalization & & State Anxiety & 0.933 & 0.437 & 0.905 & 2.133 & 0.279 \\
\hline 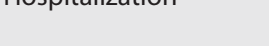 & $\mathrm{No}$ & Constant & 1.136 & 2.282 & 0320 & 4.155 & $0.000 *$ \\
\hline & & State Anxiety & 0.181 & 0.044 & & & \\
\hline
\end{tabular}

Tablo 5. The Effect of Insomnia Severity on Trait Anger

\begin{tabular}{|c|c|c|c|c|c|c|c|}
\hline Variable & Group & Model & \multicolumn{2}{|c|}{ Unstandardized Coefficients } & $\frac{\text { Standardized Coefficients }}{\text { B }}$ & $\mathbf{t}$ & $\mathbf{p}$ \\
\hline General Situation & & Insomnia Severity & 0.292 & 0.045 & 0.304 & 60.420 & $0.000^{*}$ \\
\hline \multirow{2}{*}{ Profession } & Doctor & Insomnia Severity & 0.289 & 0.063 & 0.275 & 4.610 & $0.000^{*}$ \\
\hline & Nurse & Constant & 17.469 & 0.901 & 0.340 & 4.326 & $0.000^{*}$ \\
\hline \multirow{3}{*}{ Gender } & Female & Insomnia Severity & 0.194 & 0.060 & 0.207 & 3.242 & $0.001^{*}$ \\
\hline & \multirow{2}{*}{ Male } & Constant & 16.526 & 0.763 & \multirow{2}{*}{0.426} & \multirow{2}{*}{6.095} & \multirow{2}{*}{$0.000^{*}$} \\
\hline & & Insomnia Severity & 0.427 & 0.070 & & & \\
\hline \multirow{2}{*}{$\begin{array}{l}\text { Result of Covid-19 } \\
\text { Test }\end{array}$} & \multirow{2}{*}{ Pozitive } & Constant & 18.663 & 0.527 & \multirow{2}{*}{0.267} & \multirow{2}{*}{1.207} & 0242 \\
\hline & & Insomnia Severity & 0.267 & 0.222 & & & 0.242 \\
\hline History of Covid-19 & Yes & Insomnia Severity & 0.283 & 0.086 & 0.269 & 3.293 & \\
\hline Contact & No & Constant & 17.241 & 0.614 & 0.323 & 5527 & 0000 * \\
\hline & No & Insomnia Severity & 0.294 & 0.053 & 0.323 & 3.521 & 0.000 \\
\hline & Yes & Constant & 16.845 & 3.755 & 0,057 & 0057 & 0964 \\
\hline Hosnitalization & res & Insomnia Severity & -0.024 & 0.429 & & & \\
\hline Hospitalization & No & Constant & 19.012 & 0.926 & 212 & & \\
\hline & NO & Insomnia Severity & 0.207 & 0.077 & 0.212 & 2.672 & $0.008^{*}$ \\
\hline
\end{tabular}


Tablo 6. The Effect of Emotion Regulation Difficulty on Trait Anger

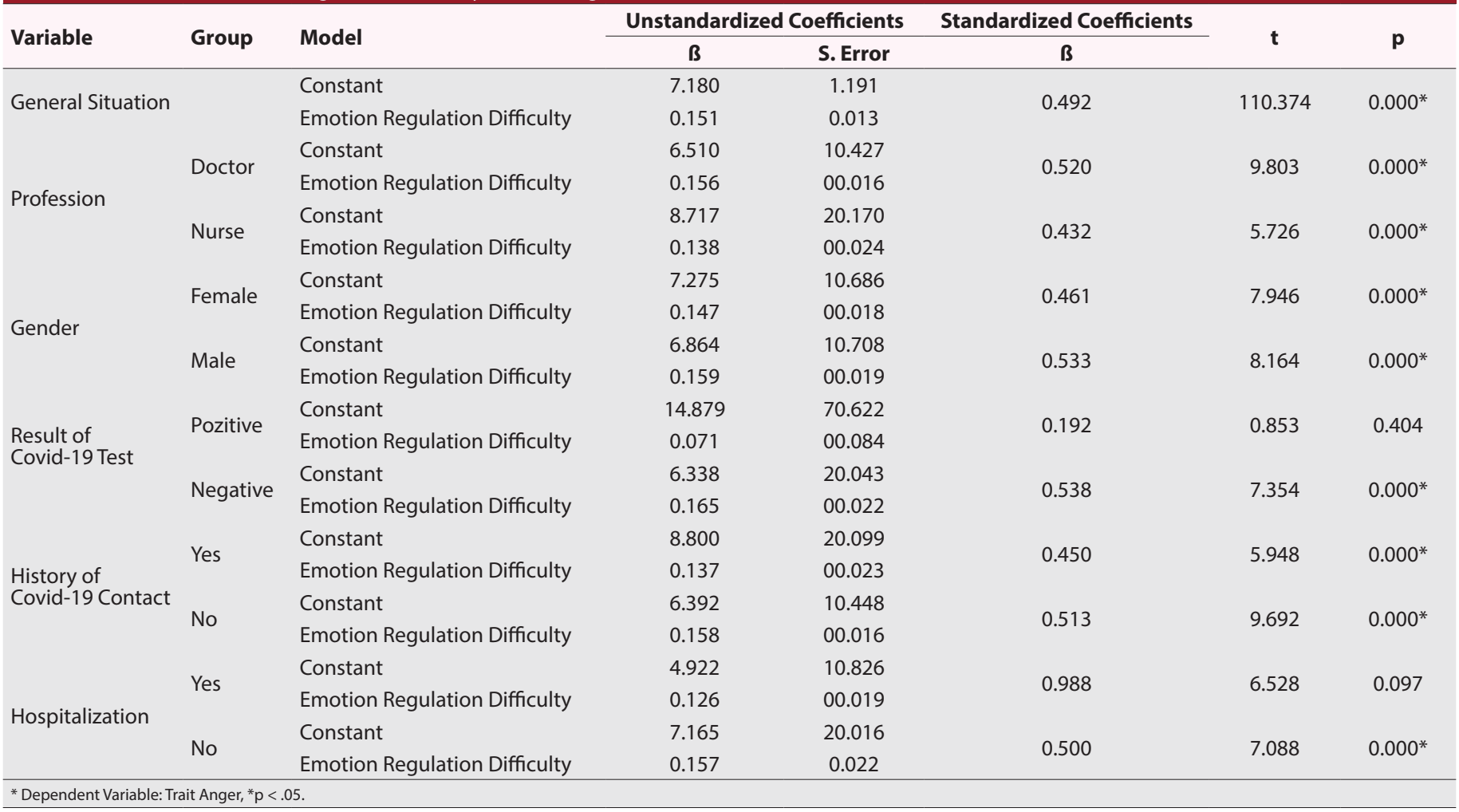

As a result of the research, it was determined that the state anxiety level of healthcare professionals correlated positively with the level of trait anger and insomnia severity and the level of emotion regulation difficulty with the level of trait anger and the level of insomnia severity with the level of trait anger.

However, whether the COVID-19 test result is positive or negative is not a significant predictor of the effect of state anxiety and emotion regulation difficulty on trait anger. No positive relationship was found between the state anxiety and emotion regulation difficulty level with trait anger level in all healthcare professionals with positive and negative results ( $p>0.05)$.

Moreover, COVID-19 test result and hospitalization eliminates the significant effect of state anxiety and insomnia severity on trait anger. The relationship which shows positive correlation between state anxiety on insomnia severity and between emotion regulation difficulty and trait anger disappear in the case of hospitalization.

\section{DISCUSSION}

Even if the clear effect of the COVID-19 pandemic on global mental health has not been recorded and measured yet, literature knowledge has shown that healthcare professionals can develop psychiatric disorders after dealing with stressful social occurrences..$^{32,33}$ The fact that COVID-19 is transmissible from person to person, associated with high morbidity and potentially being fatal can intensify the perception of the individual's danger. In addition, the insufficiency of materials that may happen due to uncertainty of the process and increase of COVID-19 cases cause the pressure on healthcare professionals and the anxiety. ${ }^{4,5}$

In pandemia, healthcare professionals are exposed to factors such as high risk of infection transmission, change of work routines, disappointment, stigma, isolation, patients who have negative feelings, lack of contact with their families and fatigue. The stressful situation created by the pandemia causes mental health problems such as anxiety, depressive symptoms, insomnia, denial, anger and fear. These mental health problems not only affect the attention, comprehension and decisionmaking ability of healthcare professionals, but also prevent the fight against COVID-19 and have a lasting impact on general mental health. Checking this situation is important to protect long-term mental health of medical healthcare professionals and to control epidemia. ${ }^{34,35}$

In a survey study conducted with 7236 participants; anxiety levels, depressive symptoms, sleep quality were determined respectively, $35.1 \%, 20.1 \%, 18.2 \%$ and the public was under a great mental health burden during the COVID-19 pandemic in China, especially young people and healthcare professionals were found to be at risk for mental disorders. ${ }^{7}$ In a study comparing 1255 non-medical healthcare professionals and 927 medical healthcare professionals, insomnia, anxiety, depression, somatization and obsessive compulsive symptoms were found significantly higher in medical healthcare professionals. ${ }^{36}$ In a cross-sectional study, an online questionnaire was applied 
to 2042 healthcare professionals and 257 administrative staff and the levels of fear, anxiety and depression were compared. Healthcare professionals were found to experience 1.4 times more fear, twice as much more depression and anxiety. ${ }^{37}$ Only healthcare professionals were included in our study and it is not possible to compare with the general population sample, but increased anxiety, anger, insomnia severity and emotion regulation difficulty are among our findings.

In a multicenter study conducted with 764 nurses and 493 doctors, the participants reported $50.4 \%$ of symptoms of depression, $44.6 \%$ anxiety, 34\% insomnia and $71.5 \%$ acute stress. Symptom levels were higher in those working with patients diagnosed with COVID-19, in women, for those working in Wuhan and in nurses..$^{38}$ In a study conducted with 230 participants in the pandemic hospital, the frequency of anxiety was $23.04 \%$ and the incidence of post-traumatic stress disorder was $27.39 \%$, and the risk was higher in nurses and female staff. ${ }^{39}$ According to the data of our study, working with patients diagnosed with COVID-19 does not affect the level of symptoms, but the state anxiety level in women and midwives/ nurses; trait anger level in healthcare professionals under the age of 35; emotion regulation difficulty in women were found to be significantly higher.

In a study conducted with 123 participants in Wuhan, 38\% of the participants had sleep disorder and a significant correlation was determined between sleep disorder and working with pediatric patients and depression scores. ${ }^{40}$ In a study comparing 2110 healthcare professionals and 2158 students via online survey, psychological stress was determined significantly higher in healthcare professionals and insomnia severity was reported to be significantly higher in healthcare professionals in Wuhan. ${ }^{41}$ In a study conducted with 180 healthcare professionals working in COVID-19 service in China, social support levels were significantly associated with self-efficacy and sleep quality and negatively correlated to the degree of anxiety and stress. Anxiety levels were significantly associated with stress levels that negatively affect self-efficacy and sleep quality..$^{19}$ In our study, the severity of insomnia in healthcare professionals is high and insomnia severity is significantly higher in women, midwives/nurses, healthcare professionals under the age of 35, unmarried ones, those who work over 8 hours a day, those who have hospital watches 2 or more times a week. Moreover, the level of anxiety and insomnia severity and insomnia severity and anger levels were found to be significantly related. While hospitalization eliminates these two significant correlations, negative results of COVID-19 test removes the significant effect of insomnia severity on the level of trait anger. The situation may be about the passing acceptance stage of the disease after hospitalization and relevant with the continuing fears of prognosis for people whose test result is positive.

In an online survey study involving 183 doctors and 811 nurses, symptoms of anxiety, insomnia and acute stress were examined, $36 \%$ had sub-threshold symptoms, $34.4 \%$ had mild symptoms, $22.4 \%$ had moderate symptoms, and $6.2 \%$ serious symptoms were detected. Relationship between high symptom cluster and contact history, less access to psychological material and resources via media have been reported..$^{42}$ In our study, no correlation was found between the history of contact and symptom level.

In a study with 38 doctors and nurses working in COVID-19 related services and 21 doctors and nurses working in other departments, significant levels of depression and anxiety were found, and no difference was found between those who worked in the service associated with COVID-19 and who did not work. ${ }^{43}$ In our study, approximately two-thirds of the healthcare professionals work in services associated with COVID-19, and there was no significant difference between those who worked in the COVID-19 service and those who did not work in terms of symptom of anxiety, anger, insomnia and emotion regulation difficulty.

The most limitation of the study is that the tests were applied online.

\section{CONCLUSION}

Health systems around the world are under high pressure and systematic interventions for mental health services are urgently needed for medical staff. ${ }^{44-46}$ These actions can show us ways to better control the COVID-19 pandemia, taking into account that the psychological problems of healthcare professionals can affect their attention, comprehension and decision making. Thus, more serious mental disorders can be prevented by early intervention. As a result, more comprehensive studies involving different aspects of being affected are needed to understand the pandemic's psychological effects more clearly. As we have seen in the literature, studies examining the pandemic's psychological effects on healthcare professionals are limited and no study on anger and emotion regulation difficulty. We think that our study will contribute to the literature and psychological rehabilitation studies during and after the pandemia..

\section{ETHICAL DECLARATIONS}

Ethics Committee Approval: Ethics committee approval for the study, numbered 46418926-050.03.04, dated 24.04.2020, was received from Hamidiye Scientific Research Ethics Committee of Health Sciences University.

Informed Consent: All patients signed the free and informed consent form.

Referee Evaluation Process: Externally peer-reviewed. Conflict of Interest Statement: The authors have no conflicts of interest to declare.

Financial Disclosure: The authors declared that this study has received no financial support.

Author Contributions: All of the authors declare that they have all participated in the design, execution, and analysis of the paper, and that they have approved the final version.

Acknowledgements: We would like to thank endlessly all the healthcare professionals who got round and participated our study in this rough time. 


\section{REFERENCES}

1. Lu H, Stratton CW, Tang YW. Outbreak of pneumonia of unknown etiology in Wuhan, China: The mystery and the miracle. J Med Virol 2020;92(4):40402.

2. Zhu N, Zhang D, Wang W, et al. Novel Coronavirus from Patients with Pneumonia in China, 2019. N Engl J Med 2020;382(8):727-33.

3. Zhou $P$, Yang $X L$, Wang $X G$, et al. A pneumonia outbreak associated with a new coronavirus of probable bat origin. Nature 2020;579(7798):270-3.

4. Li Q, Guan X, Wu P, et al. Early Transmission Dynamics in Wuhan, China, of Novel CoronavirusInfected Pneumonia. N Engl J Med 2020;382:1199-207.

5. Hsu LY, Chia PY, Lim JF. The Novel Coronavirus (SARS-CoV-2) Epidemic. Ann Acad Med Singapore 2020;49(3):105-7.

6. Gold JA. Covid-19: adverse mental health outcomes for healthcare workers. BMJ 2020;369:m1815.

7. Lim TK. The Facts, Fallacies and Uncertainties about Coronavirus Disease 2019 (COVID-19). Ann Acad Med Singapore 2020;49(6):343-5.

8. Ong EK, Lim CH, Wong A JYT. The Role of Social Media during the COVID-19 Pandemic. Ann Acad Med Singapore 2020;49(6):408-10.

9. TC. Sağlık Bakanlığı, COVID-19 bilgilendirme sayfası, 2020. Available online: https://covid19bilgi.saglik.gov.tr/tr/

10. Huang Y, Zhao N. Chinese mental health burden during the COVID-19 pandemic. Asian J Psychiatr 2020;51:102052.

11. Cullen W, Gulati G, Kelly BD. Mental health in the COVID-19 pandemic. QJM 2020;113(5):311-2.

12. Ree MJ, French D, Macleod C, et al. Distinguishing cognitive and somatic dimensions of state and trait anxiety: development and validation of the state-trait Inventory for cognitive and somatic anxiety (STICSA). Behav Cognit Psychother 2008;36(03):313-32.

13. Ahorsu DK, Lin CY, Imani V, et al. The Fear of COVID-19 Scale: Development and Initial Validation. Int J Ment Health Addict 2020;27:1-9.

14. Lin CY. Social reaction toward the 2019 novel coronavirus (COVID-19). SoC Health Behav 2020;3(1):1-2.

15. Tan BYQ, Chew NWS, Lee GKH, et al. Psychological Impact of the COVID-19 Pandemic on Health Care Workers in Singapore. Ann Intern Med 2020;6:M20-1083.

16. Alkan H, Gürler SA, Akcanca N. Investigation of these different variables and anger levels, anger axpression styles of child development program students. EPESS 2018;10:23-9.

17. Mok E, Chung BP, Chung JW, et al. An exploratory study of nurses suffering from severe acute respiratory syndrome (SARS). Int J Nurs Pract 2005; 11:150-60.

18. Xiao $H$, Zhang $Y$, Kong $D$, et al. The Effects of social support on sleep quality of medical staff treating patients with coronavirus disease 2019 (COVID-19) in January and February 2020 in China. Med Sci Monit 2020;26:e923549.

19. Chew NWS, Lee GKH, Tan BYQ, et al. A multinational, multicentre study on the psychological outcomes and associated physical symptoms amongst healthcare workers during COVID-19 outbreak. Brain Behav Immun 2020;21:S0889-1591(20)30523-7.

20. Koole SL. The psychology of emotion regulation: an integrative review. Cognition and Emotion 2009;23(1):4-41.

21. Nezamipour $E$, Ahadi $H$. The effect of cognitive emotion regulation strategies on the relationship between personality traits and quality of life in dialysis patients. Qom Univ Med Sci J 2016;10(2):70-80.

22. Yazıcıoğlu Y, Erdoğan S. Spss uygulamalı bilimsel araştırma yöntemleri. Ankara: Detay Yayıncılık. 2004.

23. Spielberger CD, Gorsuch RL, Lushene RE. Stai. Manual for the State-Trait Anxiety Inventory (Self Evaluation Questionnaire). Palo Alto California: Consulting Psychologist. 1970;22:1-24.

24. Öner N, Le Compte A. Durumluk-Süreklilik Kaygı Envanteri el kitabı. 2.Basım. İstanbul:Boğaziçi Üniversitesi Yayınları. 1998.

25. Spielberger CD, Jacobs GA, Russell S, et al. "Assessment of Anger:The State-trait Anger Scale". In J.N. Butcher ve C.D. Spielberger (Eds.), Advances in Personality Assessment (S.2:161-189), Lawrence Erlbaum:Hillsdale, NJ. 1983.
26. Özer AK. Sürekli Öfke (SL-Öfke) ve Öfke İfadesi Tarzı (Öfke-Tarz) Ölçekleri ön çalışması, Türk Psikoloji Derg 1994;9(31):26-35.

27. Bastien $\mathrm{CH}$, Vallieres A, Morin CM. Validation of the Insomnia Severity Index as an outcome measure for insomnia research. Sleep Med 2001;2:297-307.

28. Boysan $M$, Güleç $M$, Beşiroğlu $L$, et al. Uykusuzluk Şiddeti İndeksi'nin Türk örneklemindeki psikometrik özellikleri. Anadolu Psikiyatri Derg 2010;11(3):248-252.

29. Gratz KL, Roemer L. Multidimensional assessment of emotion regulation and dysregulation: Development, factor structure, and initial validation of the Difficulties in Emotion Regulation Scale. J Psychopathol Behav Assess 2004;26:41-54.

30. Ruganc RN. The relationship along attachment style, affect regulation, psychological distress and mental construction of the relational world. Yayınlanmamış doktora tezi, Orta Doğu Teknik Üniversitesi, Psikoloji Bölümü;2008.

31. Torales J, O'Higgins M, Castaldelli-Maia JM, Ventriglio A. The outbreak of COVID-19 coronavirus and its impact on global mental health. Int J Soc Psychiatry 2020;66(4):317-20.

32. Lung FW, Lu YC, Chang YY, et al. Mental symptoms in different health professionals during the SARS attack: a follow-up study. Psychiatr $Q$ 2009;80(2):107-16.

33. Maunder RG. Was SARS a mental health catastrophe? Gen Hosp Psychiatry 2009;31(4):316-7.

34. Kang L, Li Y, Hu S, et al. The mental health of medical workers in Wuhan, China dealing with the 2019 novel coronavirus. Lancet Psychiatry 2020;7(3):e14.

35. Goh SSN, Chia MYC. Anxiety and morale in front-line healthcare workers during the coronavirus disease 2019 (COVID-19) outbreak at the National Screening Centre in Singapore. Ann Acad Med Singapore 2020 Mar 16;49(3):155-60.

36. Zhang WR, Wang K, Yin L, et al. Mental health and psychosocial problems of medical health workers during the COVID-19 Epidemic in China. Psychother Psychosom 2020;89(4):242-50.

37. Lu W, Wang $H$, Lin $Y$, et al. Psychological status of medical workforce during the COVID-19 pandemic: A cross-sectional study. Psychiatry Res 2020;288:112936.

38. Lai J, Ma S, Wang Y, et al. Factors Associated With Mental Health Outcomes Among Health Care Workers Exposed to Coronavirus Disease 2019. JAMA network open 2020;3(3):e203976.

39. Huang JZ, Han MF, Luo TD, Ren AK, Zhou XP. Zhonghua Lao Dong Wei Sheng Zhi Ye Bing Za Zhi 2020;38(3):192-5.

40. Wang S, Xie L, Xu Y, et al. Sleep disturbances among medical workers during the outbreak of COVID-2019. Occup Med (Lond) 2020;70(5):364-9.

41. Wu W, Zhang Y, Wang P, et al. Psychological stress of medical staffs during outbreak of COVID-19 and adjustment strategy. J Med Virol 2020;1-9.

42. Kang L, Ma S, Chen M, et al. Impact on mental health and perceptions of psychological care among medical and nursing staff in Wuhan during the 2019 novel coronavirus disease outbreak: A cross-sectional study. Brain Behav Immun 2020;87:11-7.

43. Liang Y, Chen M, Zheng X, et al. Screening for Chinese medical staff mental health by SDS and SAS during the outbreak of COVID-19. J Psychosom Res 2020;133:110102.

44. The Lancet. COVID-19: protecting health-care workers. Lancet. 2020;395(10228):922.

45. Wickramasinghe $\mathrm{KK}$, Ishara $\mathrm{MH}$, Liyanage $\mathrm{P}$, et al. Outcome-based approach in development of a disaster management course for healthcare workers. Ann Acad Med Singapore 2007;36(9):765-9.

46. Ho CS, Chee CY, Ho RC. Mental health strategies to combat the psychological impact of COVID-19 beyond paranoia and panic. Ann Acad Med Singapore 2020;49(3):155-60. 